\title{
The Drinking Cultures of the Higher Classes
}

On the guests being seated at the table: It is not unusual, where taking wine is en regle [customary], for a gentleman to ask a lady to take wine until the fish or soup is finished, and then the gentleman honoured by sitting on the right of the hostess, may politely inquire if she will do him the honour of taking wine with him. This will act as a signal for the rest of the company ... at many tables, however, the custom or fashion of drinking wine in this manner is abolished, and the servants fill the glasses of the guests with various wines suited to the course which is in progress. ${ }^{1}$

If working-class drinking can be described as humdrum and routine then in contrast, the drinking culture of the higher classes involved a bit more show and spectacle. There was a desire to consume alcohol in a conspicuous manner in order to reflect and promote social status and the key ways of doing so were to consume the 'right' sorts of drinks in the 'right' kind of places. The quote above from Mrs Beeton's Book of Household Management describes the protocol for serving alcohol at dinner parties. ${ }^{2}$ For many middle- and upper-class men and women, drinking wine with meals formed an intrinsic part of the daily routine-much like the dinner beer of the working classes. Davidoff argues that imperial notions of civility and social duty governed dining and entertaining, which were the central aspects of Victorian middle- and upper-class social life. ${ }^{3}$ The domestic context of alcohol consumption was governed by rules of social etiquette, which both demonstrated and reinforced social class and gender values. Within middle- and upper-class homes purchasing, serving

(C) The Author(s) 2018

T. Hands, Drinking in Victorian and Edwardian Britain, https://doi.org/10.1007/978-3-319-92964-4_12 
and consuming good quality wines and spirits were key ways to demonstrate levels of cultural capital and good taste. Writing in 1853, Charles Dickens observed that

Nothing in domestic economy tells more of home comfort and consequently of home happiness, than the quality and condition of the wine and the manner in which it is served ... without a good wine, a dinner is worthless. ${ }^{4}$

Dickens wrote an article in Household Words that offered advice on purchasing, keeping and consuming wines and spirits. He argued that despite the glut of domestic cookery manuals, few had tackled the issue of buying and serving wines to be consumed within the home. ${ }^{5}$ Dickens believed that good quality wines and spirits were a necessary accompaniment to dinner and that bad wine was 'abhorrent' to good hospitality. ${ }^{6} \mathrm{He}$ therefore instructed his readers on how to serve good quality wines for dining and entertaining. The main wines consumed with dinner were port, sherry, Burgundy, Claret and Hock and when entertaining at evening parties, good quality champagne was served to guests. ${ }^{7}$ Dickens emphasised the importance of sourcing only the best quality wines and spirits from reputable wine merchants but there were other retail options.

In the wake of The 1860 Wine and Refreshment Houses Act, the wine retail market flourished and businesses like the Victoria Wine Company built a reputation and success through establishing a nationwide chain of shops selling good quality wines and spirits. ${ }^{8}$ In addition, the 1860 Act also stimulated the growth of the off-license trade which lead to the expansion of licensed grocers. Therefore in the second half of the nineteenth century, good quality wines, beers and spirits could be purchased in a range of retail outlets. Many middle- and upper-class homes held accounts with local wine merchants and licensed grocers, and in most cases, women managed the purchase of alcohol. In The Book of Household Management, Mrs Beeton described wine as an essential household commodity. Her domestic guide outlined strict rules regarding the use and consumption of alcohol-from wine use in entertaining to paying the servants their beer allowance. For Mrs Beeton and her middle-class female readership, knowledge of the correct and desirable use and consumption of wine was essential because domestic dining was the domain of women and as such it was governed by gendered rules. 
For middle- and upper-class women, domestic dining, entertaining and social engagements were some of the few occasions in which it was considered permissible for women to drink alcohol and as with working class women, respectable drinking had to fall under the male gazehence the moral panic in the late nineteenth century regarding women's access to alcohol through medical prescriptions and licensed grocers which were both believed to have led to the reported rise in 'secret drinking' among women of the higher classes. Although it was morally permissible for women to drink at some social occasions, there were concerns that they somehow craved alcoholic intoxication more than men and consequently were unable to govern their passions. Following the publication of an article on 'drawing room alcoholism' in The Saturday Review in 1871, there was much debate in the press regarding middleand upper-class women's drinking habits. Many of the regional papers ran opinion pieces speculating on the causes and consequences of the perceived rise in women's drinking

Women seldom drink for gratification of their palate and the pitiable dram drinker sometimes loathes the spirit she gulps down. Good or bad wine, potato brandy, curacao or gin will satisfy her if only her nervous organisation be sufficiently saturated. The volume of light wine or beer sometimes taken is almost incredible ... The test of safety in the modern use of alcoholic drinks seems to be the power in the persons of fair health to leave off their accustomed beer or sherry without inconvenience or moral effort. This test might be occasionally applied by rational women to themselves or insisted by their mankind.?

Dinner parties were some of the few social occasions where middle- and upper-class women could drink for gratification and do so in a manner that was deemed respectable. The same degree of moral scrutiny and control did not apply to the drinking habits of middle- and upper-class men, for whom dinner parties in the home were only one potential site of alcohol consumption. Some of the interviewees in The Edwardians study recalled their fathers drinking and dining in the gentlemen's clubs that were situated in and around Pall Mall and St James's in London

Interviewer (I): Did he [father] belong to any clubs?

Interviewee (LP): Yes.

$I$ : What were they? 
LP: He belonged to the Oxford and Cambridge and he belonged to the Carlton and he belonged to the Marlborough. King Edward put him up for The Marlborough and I think he belonged to of course a lot of Conservative Clubs and sort of country clubs and things, those were the London Clubs he belonged to.

I: Did he go to them a lot?

LP: Yes. Oxford and Cambridge he went a lot.

I: On what occasions did he go there? To eat or when they were having a debate?

LP: Oh he went there to eat and very often lunched there and usually went in there in the evening. ${ }^{10}$

For men of the higher classes, gentlemen's clubs offered an alternative to the domestic sphere by providing private spaces for socialising, networking, dining, drinking and entertaining. In a study of late nineteenthcentury London Clubs, Amy Milne-Smith describes gentlemen's clubs as places where middle- and upper-class men forged their class and gender identities. ${ }^{11}$ The London Clubs flourished in the nineteenth century and between 1880 and 1914 there were 75 clubs located in the West End of London and all were exclusively for men. ${ }^{12}$ Regional gentlemen's clubs also gained popularity in the late Victorian period. For example, The Western Club in Glasgow which was founded in 1825 for the purposes of providing its members with 'cheap and well-cooked dinners' and 'wine free of death in the bottle'. ${ }^{13}$ The Western Club was established to cater for the needs of middle- and upper-class men living in Glasgow and the surrounding areas by providing overnight accommodation and a private space for dining and entertaining. Gentlemen's clubs were run as either commercial ventures or more commonly as members-only clubs, which were formed through mutual interests and associations. The most popular clubs with the largest numbers of members were political and military clubs but other clubs were formed through mutual interests in art, literature, sport, travel and school or university affiliation.

Some of the upper-class interviewees in the Edwardians study referred to their fathers as 'club men' meaning that they spent a good deal of their leisure time dining and socialising in one or several of the West End Clubs. Club men were composed of politicians; landed gentry; doctors; businessmen; militarymen; clergymen; and writers and artists. These were men from different social backgrounds who shared a similar desire to socialise privately but also conspicuously within clubs that offered 
both a means of social escape and a way to cultivate and display social status. Milne-Smith believes that 'clubs were relevant to a much broader spectrum of the population than their members alone and the Club is an entry point into issues of class, gender and social life in Britain.' ${ }^{14}$ Gentlemen's clubs are also an entry point into issues surrounding alcohol consumption and the drinking cultures of the upper classes which often escaped public scrutiny.

\section{Guardians of Taste: The Drinking Culture of Victorian Gentlemen's Clubs}

Most of the private members clubs had organising committees and subcommittees charged with various tasks that contributed to the running of the club. As dining and drinking were central and important aspects of club life, many of the London Clubs had wine committees that were responsible for sourcing, selecting and purchasing the alcoholic drinks sold within Clubs. The archival records of two London Clubs, The Athenaeum and The Reform Club, offer insights into the ways in which the wine committees operated in the late nineteenth century. The Athenaeum was founded in 1824 for the purpose of providing a social venue for gentlemen with shared interests in the arts, literature and science. The Reform Club was established in 1836 and started out initially as a political club for members associated with the Liberal party. By the last quarter of the nineteenth century, both clubs, although founded for different purposes, were attracting men who moved in similar circles. ${ }^{15}$ Sir Arthur Conan Doyle was a member of both the Athenaeum and the Reform Clubs and indeed many men held membership of several West End Clubs where they dined and drank regularly. ${ }^{16}$ In a history of The Athenaeum Club, written by one of its members Mr F. R. Cowell, the author praised the work of the Club's successive wine committees

Such a tribute is more necessary because histories of Clubs do not usually have much to say about wine, which matters less because memories of vanished vintages and long-forgotten wine lists can be merely tantalising irrelevancies to those with no hope of profiting from either. That many members of the Athenaeum can recall Cockburn's '27 port and other splendid wines is small consolation to them or anyone else now that stocks are exhausted. ${ }^{17}$ 
Cowell applauded the 'vigilance and skill' of wine committees in ensuring that 'splendid' and memorable wines were served within The Athenaeum. The club members who served on wine committees were expected to liaise with wine merchants, select and sample various wines, beers and spirits and ensure that the Club was stocked with the best quality alcoholic drinks. In this sense the wine committees acted as guardians of taste within gentlemen's clubs. Bourdieu argues that the consumption of goods is one way in which the concept of taste can be used to define and demonstrate social class status. ${ }^{18}$ Bourdieu uses the example of art to show that art appreciation is a decoding operation in which the consumer possesses and uses the ability or education to unlock and understand the meaning or cultural code in a work of art. In a similar way, wine appreciation is also a decoding operation in which the consumer must possess the necessary skills and education in order to make informed judgements on the quality of wine. Educated judgements and appreciation of art or wine require a certain degree of cultural capital that was most evident in people from higher social class backgrounds. Being able to crack the cultural code in objects and consumer goods was a key way to cultivate and display social status and to delineate concepts of good taste.

Bourdieu argues that the taste of the working classes is the taste of necessity and function, whereas the taste of the higher classes is one of liberty or luxury. ${ }^{19}$ The wine committees within Victorian gentlemen's clubs were tasked with cultivating and upholding particular standards of taste in alcoholic drinks which mirrored the social status of club members. Although The Athenaeum and The Reform Clubs were formed through mutual interest and associations, the club members were drawn from different social circles and therefore brought with them differing levels of cultural capital which would have either enhanced or diminished their knowledge and appreciation of alcoholic drinks. However, the clubs had certain standards of taste to uphold and adhere to and these tastes did indeed reflect concepts of liberty and luxury. The men who drank in the clubs had the freedom and finances that allowed them to do so and they expected to be served only the finest quality alcoholic drinks. As guardians of taste, the wine committees did indeed exert considerable 'vigilance and skill' in ensuring that the alcohol consumed in The Athenaeum and The Reform Clubs reflected the class and gender status of club members. 
The wine committees of both clubs spent a good deal of time and money choosing the 'right' wines, spirits, liqueurs, beers, cigars and cigarettes. Both clubs dealt with several local wine and spirit merchants and purchased various types of drinks from different suppliers. The Reform Club's wine and cigar committee records from 1889 to 1904 contain detailed information on the selection and purchase of alcohol. ${ }^{20}$ Committee meetings were held regularly and consisted of dealing with wine merchants, reaching decisions on sample tastings, placing or rejecting orders and managing accounts. The committee sampled different types of wines, spirits, champagnes and liqueurs and orders were based upon the tasting sessions. Effectively this meant that the types of alcoholic drinks sold within the Club were constantly changing. Between 1889 and 1904 The Reform Club dealt with four wine and spirit merchants: Claridge, Cockburn, Alnutt and Campbell. The Club also held accounts with major English brewers such as Ind Coope, Whitbread and Alsopp. The wine list for 1891 detailed the types of alcoholic drinks sold within the Club. The list was organised into categories of drinks, for example: port; sherry and madeira; champagne; claret; Moselle; Burgundy; Chablis and Sauterns; Australian; Hungarian; Italian; Greek; liqueurs; spirits; mineral waters. In each category there were 14 types of port; 14 types of sherry; 37 types of champagne; 10 types of Hock; 35 types of Claret; 5 types of Moselle; 13 types of Burgundy; 2 types of Chablis; 6 types of Sauterne; 6 types of Australian wine; 2 types of Hungarian wine; 5 types of Italian wine and 3 types of Greek wine. The liqueurs and spirits section included: Absinthe; Benedictine; Angostura; Vermouth; brandy liqueurs; Curacoa; brandy; rum; gin; Hollands and whisky-Irish and Scotch. The beers and ales sold were Allsopp; Bass; Burton; Scotch; Whitbreads extra stout; Stout; Guinness; Pilsner Lager Beer; Bass's Ale; Ind Coope's table beer and cider. The wine list also contained information on the vintage, date of purchase and price of the drinks. ${ }^{21}$ Another wine list from 1899 contained 2 sections: Club wine and Merchants wine. The Merchants' Wines were marginally more expensive than the Club Wines which were sold to Club members without a significant markup on the retail price-for example, Giesler Extra Super Dry Champagne bought for $6 \mathrm{~s} 7 \mathrm{~d}$ per bottle was sold in the Club for $7 \mathrm{~s} 9 \mathrm{~d} .{ }^{22}$

The sale of wines and spirits generated modest profits but greater profits could also be made by investing in stocks of wines that would 
potentially increase in value and therefore contribute to the assets of the Club. In a history of The Reform Club, Woodbridge states that wine and spirits have always made the largest contributions to the profits from the sale of provisions and claims that the Club's leading assets between 1840 and 1910 were its stocks of wines and spirits. ${ }^{23}$ The Athenaeum wine committee operated in a similar way to that of The Reform Club and as Graph 12.1 shows, wise investment in wine generated income for the Club.

The graph shows a fluctuating profit margin from sales of alcohol because periodically, stocks of wine would be put up for sale to Athenaeum Club members. For example in 1900, stocks of 1868 Madeira and 1874 Claret were released for sale and this may have accounted for the larger profits generated from the sale of alcohol in that year. Private clubs were not required to pay excise duties or license fees for the sale of alcohol. In effect this meant that clubs could sell alcohol at any time of day and because there was no payment of excise duties, the alcohol sold within clubs was modestly priced. The absence of excise duties also allowed private clubs to invest in stocks of wine that could then be sold to generate more substantial profits for the club. However, investment in stocks of wine was not without risk. In a contemporary

\section{Income \& Expenditure on wines, beers \& Spirits in The Athenaeum Club}

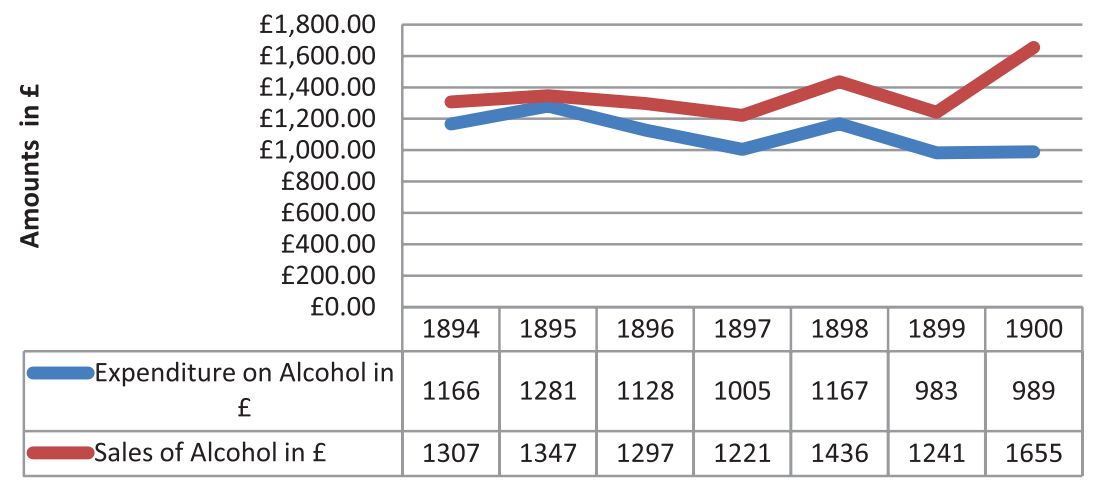

Graph 12.1 Income and expenditure on wines, beers and spirits in The Athenaeum 1894-190024 
account of London Clubs, Major Griffiths outlined the importance of wise investments

If the [wine] committee elects to depend upon the wine merchants, and buy in small quantities from time to time, it is called upworthy of the traditions of a great club; if the club keeps up a cellar facing the risk of deterioration in a large stock, or a change in taste that makes a particular wine so much dead money, no excuse is accepted for the inevitable loss entailed. One famous establishment not long since disposed of some hundreds of dozens of vintage clarets - high class Clos Vougeot, Lafitte, Mouton Rothschild, and the rest - for a mere song, because they were no longer in demand for after-dinner drinking, on account of the hunger so universally displayed for tobacco. Yet again, when a certain brand of champagne failed for some occult reason to win popularity, it was offered for removal at the price of ginger beer, and the fortunate purchasers obtained a wine which presently so improved by keeping as to rack with the best. No amende was made to the sagacious members of the wine sub-committee who had bought it originally. ${ }^{25}$

The wine committees were not only expected to purchase types of alcohol that reflected particular standards of taste but they were also tasked with the risky business of stocking wine cellars that could a generate fairly substantial incomes. Within gentlemen's clubs, the purchase and sale of alcohol were governed by a different set of social and legal rules. The licensing of private clubs was dependent upon the club being either a proprietary or private members club. In proprietary clubs, stocks of alcohol belonged to the club owner who then sold alcohol at a profit to club members - these clubs operated in much the same way as public houses or hotels. Whereas in private members clubs, stocks of alcohol belonged to all the club members who were viewed as being supplied with alcohol rather than being sold alcohol at a profit. ${ }^{26}$ This was a legal technicality which allowed private members clubs to escape the licensing laws. It was not until the Licensing Act of 1902 that private clubs were brought under any kind of legal jurisdiction. The legislation required that all private members clubs selling alcohol were registered with local justices but this did not mean that private clubs were regarded as licensed premises and therefore the sale of alcohol within clubs remained unregulated.

Clubland was viewed as a distinctly private sphere where dining, drinking and conviviality could exist without any external interference. 
Legal definitions aside, this was also because Clubmen were drawn from the social and intellectual elites. In this sense, the alcohol bought and sold within gentlemen's clubs was viewed as a respectable commodity that was consumed for reasons other than mere intoxication. Arguably, the real value of alcohol was not as an intoxicant or as a social lubricant but as a marker of education and civility. As guardians of taste, the wine committees had their work cut out because the members of The Athenaeum and The Reform Clubs had high expectations of the drinks that they consumed. Major Griffiths believed that Club habitués craved comfort, conviviality and companionship and that they were drawn to gentlemen's clubs because

The best of everything is at their disposal; material comforts and intellectual delights of the sort that appeal to them. The pleasures of the table are within easy reach; choice fare prepared by a chef who, with a more or less violent stretch of the imagination, is supposed to pass as a cordon bleu; wines of the finest vintages, if they are content to accept the committee's selection, have been laid down for them, offering the widest choice of drinks, and their perpetual absorption, if that way inclined. ${ }^{27}$

The Athenaeum and The Reform Club sold a similar range of alcoholic drinks and indeed both clubs dealt with the same wine merchants: Claridge and Alnutt. However club members did not always appreciate the selection of wines available and it was a common practice within The Athenaeum to write complaints on the reverse side of dinner bills. In 1893, one Club member, Mr Waldegrave Leslie, dined alone at the Athenaeum and drank half a bottle of Pommery Vin Brut and a glass of sherry. However the wine gave him cause for complaint

I have the honour of being a member of the Athenaeum for a great many years. The wines of the Athenaeum used to be obtained from first rate wine merchants. Why are some of these not now employed? I am not a partner in any wine merchants 'firms' - I am not connected with the wine trade in any way whatever. I protest against the liquor called wine supplied by Claridge. Who is Claridge? The so-called Pommery Vin Brut on the other side [of the bill] has never been made in the Champagne region. All Claridge's champagnes are as bad. They are not champagnes. ${ }^{28}$

Mr Waldegrave Leslie was a frequent diner who often wrote scathing remarks on the reverse of his dinner bills regarding the quality of food 
and drink sold within the Club. The marked dinner bills were kept and passed on to the Executive Committee who dealt with any complaints. The Athenaeum archive holds marked dinner bills from 1888 to 1910 and these provide insights into the type and volume of drinks that upperclass men consumed in the late Victorian period. When dining alone most men drank moderately, perhaps having a glass of sherry, a half bottle of champagne or wine and a glass of brandy and soda. However there were exceptions: one diner in 1891 had a four-course meal washed down with a pint of East India Pale Sherry, a bottle of Perrier Jouet Champagne and a glass of Chateau Leoville wine. ${ }^{29}$ Club members of both the Athenaeum and the Reform Clubs sometimes hosted dinner parties where guests or 'strangers' were invited into the Club for the evening. These dinner parties were usually accompanied with fairly lavish amounts of alcohol. In 1901, Arthur Conan Doyle invited eleven guests to dinner in the Athenaeum where they consumed 2 bottles of Pale East India Sherry; 2 bottles of Rudenheimer; 1 bottle of Chateau Palmer; 8 bottles of Moet Chandon; 2 bottles of Port; glasses of brandy and whisky; and cigars and cigarettes. ${ }^{31}$ More formal dinners included a printed invitation which contained the dinner menu, including drinks and toasts. The Reform Club with its affiliation to the Liberal Party hosted prominent dinners where members celebrated political victories. At these sorts of events, the type and quality of food and drink consumed was of paramount importance and only the finest selection of champagnes and wines were served. For example on 8 January 1924, the Reform Club hosted a dinner for members who were successful in the 1923 General Election. The drinks menu included bottles of 1815 Olorosa Sherry; Mumm Cordon Rouge Champagne; Cockburn's 1896 Port; brandy and 'fine Champagne 1865'.30

Within the London Clubs, the social status of alcohol consumers went without question-club membership was a badge of honour and an endorsement of elite status. Clubland not only escaped the licensing laws because of the social status of its drinkers and drinking venues; the alcohol consumed within the London Clubs also held an elevated status as a respectable commodity that was consumed for reasons other than mere intoxication. The private drinking culture of gentlemen's clubs was dependent upon more than a legal loophole-it was also very much dependent upon a show of respectability. One key way to achieve this was to select and consume alcohol that was imagined to be the preserve of those with the financial means to afford it and the 'right' amount of 
cultural capital to be able to fully appreciate it. In a similar way, middleand upper-class dinner parties also provided social opportunities to display wealth and social status. Knowledge of how to select and serve the best types of alcoholic drinks was important and in this way, alcohol served an important function. Although the drinking habits of the middle and upper classes evaded public scrutiny, the privacy and protection afforded by the home and by gentlemen's clubs did not diminish the conspicuous consumption of alcohol but it did largely evade the spectre of the drunkard.

\section{Notes}

1. Beeton I. 1861. The Book of Household Management: London: S. O. Beeton: p. 8.

2. Ibid.

3. Davidoff L. 1986. The Best Circles: London: Croom Helm Ltd.: p. 39.

4. Dickens C. 1853. Household Words, Volume VIII: www.djo.org.uk/household-words/volume-viii-p: accessed 15/09/2014.

5. Ibid.

6. Ibid.

7. Ibid.: p. 405 .

8. Briggs A. 1965. Wine for Sale: Victorian Wine and the Liquor Trade, 1860-1984: Chicago: University of Chicago Press: pp. 18-19.

9. 'Drawing Room Alcoholism': The Ashton Weekly Reporter: Manchester: 28 January 1871.

10. Thompson P. and Lummis T. Family Life and Work Experience Before 1918: Interview No. 2012, Male born 1882 in London. The interviewee was Lord Parmor.

11. Milne-Smith A. 2011. London Clubland: A Cultural History of Gender and Class in Late Victorian Britain: London: Palgrave Macmillan: p. 2.

12. Ibid.: p. 28.

13. The Western Club Archives: Wilkinson F. A. The Story of the Western Club: From Its Inception in 1825 to the Year 1900: booklet written by a Club member: no date.

14. Ibid.

15. Milne-Smith A.: pp. 12-15.

16. Cowell F. R. 1974. The Athenaeum: Club and Social Life in London 18241974: London: Heinemann Education Books Ltd.: p. 55.

17. Cowell F. R.: p. 100.

18. Bourdieu P. 1984. Distinction: A Social Critique of the Judgement of Taste: London: Routledge: p. xxv. 
19. Bourdieu P.: p. xxix.

20. Reform Club Archives (RCA): Wine and Cigar Committee Minutes: 1889-1904.

21. RCA: Wine and Cigar Committee Minutes: Wine List: 1891.

22. RCA: Wine and Cigar Committee Minutes: List of Wines Requiring Selling Price: 1895.

23. Woodbridge G. 1978. The Reform Club, 1836-1974: A History of the Club's Records: published by The Reform Club: p. 73.

24. The Athenaeum Archives (AA): Executive Committee Minutes: 1899-1901.

25. Griffiths A. G. F. 1907. Clubs and Clubmen: London, Hutchinson \& Co.: p. 197.

26. Manchester C. 2008. Alcohol and Entertainment Licensing Laws: London: Routledge-Cavendish: p. 334.

27. Griffiths A. G. F.: p. 203.

28. AA: Cat 1/10: Marked Bills: 1891-1897: Complaint of Mr Waldergrave Leslie.

29. AA: Cat 1/10: Marked Bills: 1891-1897.

30. AA: Cat 1/12: Marked Bills: 1901-1903.

31. RCA: Dinner Invitation: 1924.

Open Access This chapter is licensed under the terms of the Creative Commons Attribution 4.0 International License (http://creativecommons.org/licenses/ by $/ 4.0 /)$, which permits use, sharing, adaptation, distribution and reproduction in any medium or format, as long as you give appropriate credit to the original author(s) and the source, provide a link to the Creative Commons license and indicate if changes were made.

The images or other third party material in this chapter are included in the chapter's Creative Commons license, unless indicated otherwise in a credit line to the material. If material is not included in the chapter's Creative Commons license and your intended use is not permitted by statutory regulation or exceeds the permitted use, you will need to obtain permission directly from the copyright holder.

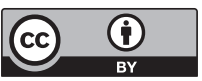

